\title{
Identification of Critical Points of Thermal Environment in Broiler Production
}

Author(s)
Menezes $A G^{1}$
Nääs IA ${ }^{2}$
Baracho MS²
1 MS in Ag. Eng. and Quality Management
Specialist. menezesag@gmail.com
2 Professor.

Mail Address

Irenilza de Alencar Nääs

College of Agricultural Engineering

Av. Cândido Rondon, 502

Barão Geraldo

Cidade Universitária Zeferino Vaz

13.083-875. Campinas, SP. Brazil

E-mail: irenilza@feagri.unicamp.br

\section{Keywords}

Broilers, hatchery, quality control.

\section{- Acknowledgement}

To CNPq for the scholarship and grant.

\section{ABSTRACT}

This paper describes an exploratory study carried out to determine critical control points and possible risks in hatcheries and broiler farms. The study was based in the identification of the potential hazards existing in broiler production, from the hatchery to the broiler farm, identifying critical control points and defining critical limits. The following rooms were analyzed in the hatchery: egg cold storage, pre-heating, incubator, and hatcher rooms. Two broiler houses were studied in two different farms. The following data were collected in the hatchery and broiler houses: temperature $\left({ }^{\circ} \mathrm{C}\right)$ and relative humidity (\%), air velocity $\left(\mathrm{m} \mathrm{s}^{-1}\right)$, ammonia levels, and light intensity (Ix). In the broiler house study, a questionnaire using information of the Broiler Production Good Practices (BPGP) manual was applied, and workers were interviewed. Risk analysis matrices were build to determine Critical Control Points (CCP). After data collection, Statistical Process Control (SPC) was applied through the analysis of the Process Capacity Index, using the software program Minitab15 ${ }^{\circledR}$. Environmental temperature and relative humidity were the critical points identified in the hatchery and in both farms. The classes determined as critical control points in the broiler houses were poultry litter, feeding, drinking water, workers' hygiene and health, management and biosecurity, norms and legislation, facilities, and activity planning. It was concluded that CCP analysis, associated with SPC control tools and guidelines of good production practices, may contribute to improve quality control in poultry production.

\section{INTRODUCTION}

Brazilian broiler meat production has grown and developed in the last few years, and has shown expressive results such as reduction of production cost, better product quality, increasing presence in the international market, increasing domestic consumption per capita, and good production performance as compared to other meat industries (Pinotti \& Paulillo, 2006).

Cesari \& Nascimento (1995) mentioned that critical points must be prevented, eliminated, or reduced to acceptable levels, which means they need to be controlled. The control of identified biological, chemical, and physical hazards is important from raw material supply up to product delivery to the consumers. The different links of the chain, such as raw materials, storage, transport, bird management, and pre-slaughter management, must be monitored and controlled for food quality and safety programs. Hazard analysis requires the assessment of two factors as to the identified risks: the probability of hazards and their severity.

Poultry production in Brazil is one of the animal production chains with the highest level of coordination, which allows it to be very competitive in the international market. As broiler meat consumption 
has increased worldwide in the last few years, consumers have become more demanding as to the quality and safety of this product. In order to export, the Brazilian poultry industry must demonstrate through documents, records (traceability), and certifications that it has standardized systems of broiler production good practices (BPGP), of critical control points (CCP), and hazard analysis and critical control points (HACCP) in place, as required by the Brazilian legislation, as well as international certification programs relative to food safety (Almeida, 1998).

The present paper describes an exploratory study aimed at identifying critical points and possible hazards in hatcheries and broiler farms.

\section{MATERIAL AND METHODS}

The study was conducted in a multiple-stage hatchery and in two farms ( $A$ and $B$ ) located in the state of São Paulo, Brazil.

The following hatchery rooms were investigated: egg cold storage, egg pre-heating, incubator, and hatcher rooms.

Data loggers $\left(\mathrm{HOBO}^{\circledR}\right)$ to record environmental temperature $(T)$ and relative humidity $(R H)$ were placed in each room. Air velocity (AV) was measured using a hygro-thermometer anemometer (HTA4200 PACER ${ }^{\circledR}$ ). In the broiler houses, ammonia was recorded using a suction pump and calorimetric tubes (DRAKER ${ }^{\circledR}$ ) and light intensity was measured using a digital lux meter $\left(\mathrm{HOMIS}^{\circledR}\right)$ according to the methodology proposed by Jones et al. (2005) and Bessei (2006). The equipment was placed in the geometrical center of each hatchery room and broiler house. Egg and newly-hatched chick surface temperatures were collected using an infrared camera (TESTO ${ }^{\circledR}$ 880).

In the hatchery, CCP analysis was carried out considering internal environment parameters
(Nicholson, 2006; Mauldin, 2007); management and biosecurity were not evaluated.

In the broiler houses, the questionnaire of the manual Broiler Good Production Practices (Boas Práticas de Produção de Frango de Corte, Embrapa, 2007) was applied and employees/farmers were interviewed. The risk analysis matrix (Dillon \& Griffith, 2001) was subsequently applied according to Equation 1 , which determines if the indicated/classified risk can be controlled after its occurrence and severity are analyzed.

\section{Risk $=$ probability of occurrence $\mathbf{x}$ severity $\quad$ Eq. 1}

The risk analysis matrix was applied to evaluate the frequency (probability of occurrence) and severity (how severe are the consequences if the incident occurs), using multiplication to obtain comparative scores (Table 1).

BPGB was evaluated according to seven classes (norms, legislation, and facilities; activity planning; management and biosecurity; poultry litter; feed; water; and workers' hygiene and health), which processes were assessed, and the set of questions corresponding to the analyzed step was presented.

After collection in the hatchery and broiler houses, data were submitted to statistical analysis using the software MINITAB $15^{\circledR}$ (Minitab, 2005), and mean comparison method. Process Statistical Control (PSC) was applied for the analysis of the Process Capacity Index to check if the process was within the specified limits (Tables 2 and 3). That index was also analyzed using $C p$ and Cpk (Equations 2 and 3).

$$
C p=\frac{\text { LSE } \cdot \text { LIE }}{6 \hat{\sigma}}
$$

\begin{tabular}{|c|c|c|c|}
\hline \multirow[t]{2}{*}{ Probability of occurrence } & \multicolumn{3}{|c|}{ Severity } \\
\hline & Low (1) & Intermediate (2) & High (3) \\
\hline Unlikely (1) & Irrelevant (1) & Tolerable (2) & Moderate (3) \\
\hline Occasional (2) & Tolerable (2) & Moderate (4) & Considerable (6) \\
\hline Likely (3) & Moderate (3) & Considerable (6) & Intolerable (9) \\
\hline Irrelevant (1) & \multicolumn{3}{|c|}{ It does not require any action, only monitoring. } \\
\hline Tolerable (2) & \multicolumn{3}{|c|}{ It requires monitoring and preventive measures. } \\
\hline Moderate (3/4) & \multicolumn{3}{|c|}{ It requires actions/efforts to reduce risk. Control Plan. } \\
\hline Considerable (6) & \multicolumn{3}{|c|}{$\begin{array}{l}\text { Work cannot be resumed until risk is reduced. If work is underway, urgent risk control measures should be } \\
\text { taken, and risk must be reevaluated. }\end{array}$} \\
\hline Intolerable (9) & \multicolumn{3}{|c|}{$\begin{array}{l}\text { Work can only be resumed after correction actions. If work is underway, work after risk reduction can only be } \\
\text { resumed after biosecurity and food safety measures are ensured. }\end{array}$} \\
\hline
\end{tabular}

Source: Adapted from Dillon \& Griffith (2001) 


$$
C p k=\operatorname{MIN}\left(\frac{\mathrm{LSE} \cdot \overline{\overline{\mathbf{x}}}}{3 \hat{\sigma}}, \frac{\overline{\overline{\mathbf{x}}} \cdot \mathrm{LIE}}{3 \hat{\sigma}}\right)
$$

where: $\mathrm{LSE}=$ Higher Specification Limit, $\mathrm{LIE}=$ Lower Specification Limit, $\overline{\bar{x}}=$ process average, and $\hat{\sigma}=$ standard deviation.

\section{RESULTS AND DISCUSSION}

\section{Hatchery}

Table 4 shows a summary of the CCPs identified in the hatchery as a result of thermal environment analysis, comparing them with the specified maximum and minimum limit values, which must be controlled to obtain better productivity indexes.

\begin{tabular}{|c|c|c|c|c|c|}
\hline Parameter & Cold storage & Pré-heating room & Incubator & Hatcher and processing & References \\
\hline $\mathrm{T}\left({ }^{\circ} \mathrm{C}\right)$ & $19-22$ & $25-27$ & $37-38$ & $35.7-37$ & $\begin{array}{l}\text { Decuypere (1992); Gustin (2003); Boerjan (2006); } \\
\text { Mauldin (2007). }\end{array}$ \\
\hline RH (\%) & $70-80$ & $? 70$ & $50-60$ & 65 & Bruzual et al. (2000); Muraroli (2003). \\
\hline ST chick & - & - & - & 38.6 & Nicholson (2006); Boerjan (2006). \\
\hline $\begin{array}{l}\text { sT egg } \\
\text { AV }\left(\mathrm{m} \mathrm{s}^{-1}\right)\end{array}$ & - & - & $37.2-38.8$ & $0 . \overline{5-3}$ & $\begin{array}{l}\text { Boerjan (2006). } \\
\text { Kaltofen (1969). }\end{array}$ \\
\hline
\end{tabular}

Table 3 - Lower and upper critical limits of tolerance adopted for broiler production.

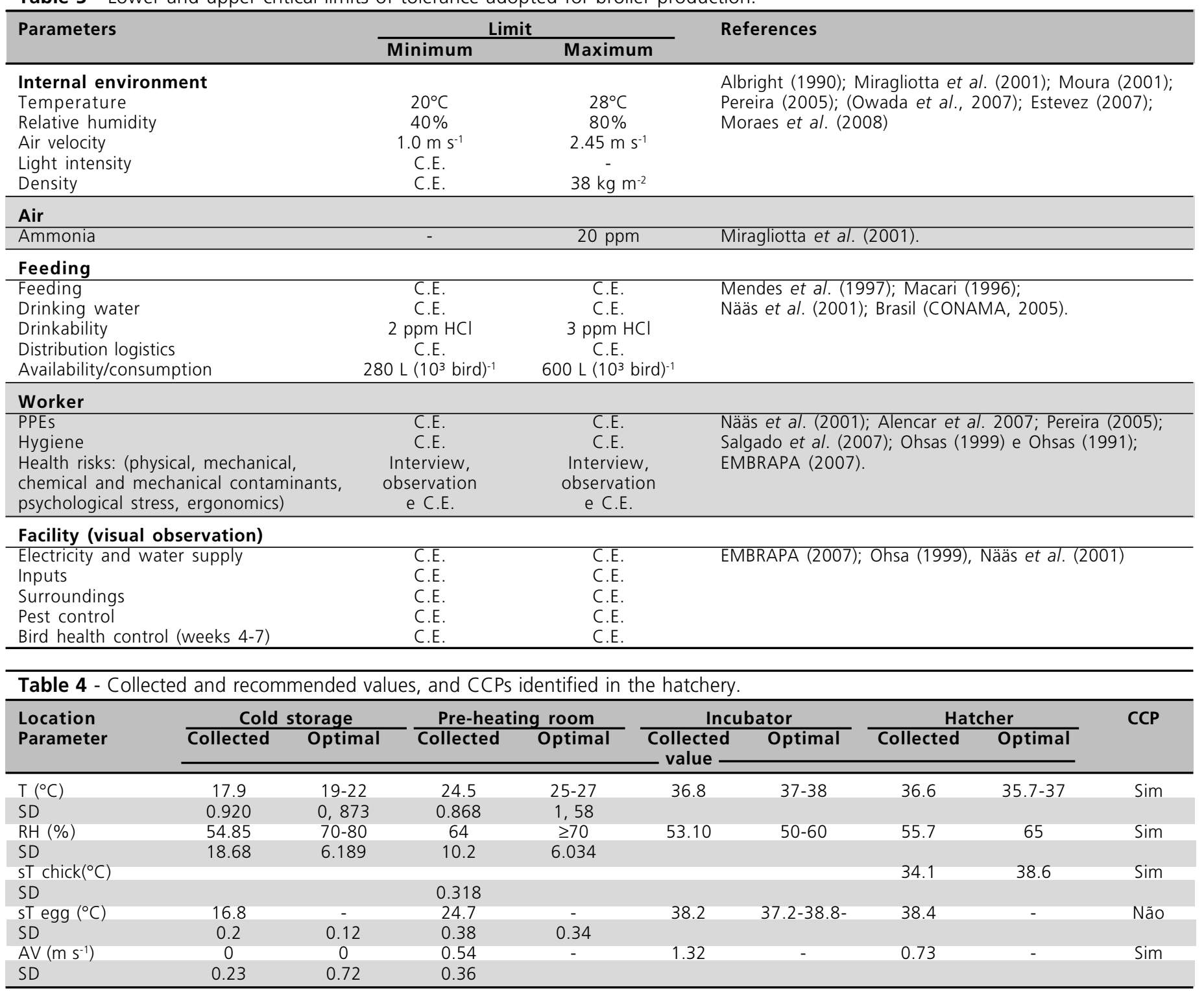

- Indicates that there is no information. $S D=$ standard deviation. 
Menezes AG, Nääs IA, Baracho MS

Average temperature recorded in the cold storage room was $17.9 \pm 0.9^{\circ} \mathrm{C}$, which is much lower than the specified environmental temperature of 19 to $22^{\circ} \mathrm{C}$ (Decuypere, 1992; Gustin, 2003; Boleli, 2003, Boerjan, 2006; Mauldin, 2007). Environmental temperature Cp index (0.54) was $<1$, which means it was stable, but outside the specified tolerance limits. The Cpk value $(-0.38)$ indicates that $87.03 \%$ of the data were below the specified lower tolerance limit (Figure 1). Average relative humidity was $54 \pm 18 \%$ and the applied $\mathrm{RH}$ tolerance limits were 70 to $80 \%$. Figure 2 shows that $\mathrm{RH}$ value was relatively stable in the analyzed environment; however, it was below the lower limit. The determined $C p$ value $(0.09)$ indicates relative variability of the collected data. The Cpk value $(-0.27)$ confirms that the process is not controlled, showing that only $19.88 \%$ of the collected data was within the specified range (70 to $80 \% \mathrm{RH}$ ), and therefore needs to be reviewed.

As to the egg pre-heating room temperature (Figure $3)$, the obtained $\mathrm{Cp}$ value used to analyze process capacity was 0.38 , outside the tolerance limits of 25 to $27 \mathrm{C}$, and that the data were symmetrical, varying between 23.1 and 24.3 C, but below the lower tolerance limit. The obtained Cpk value (-0.32) indicates that the process in not centralized within the average tolerance levels, and that only $16.51 \%$ of the values were in the range of 25 to $27^{\circ} \mathrm{C}$. Average $\mathrm{RH}$ of the egg pre-heating room was $64 \pm 6 \%$, which is below the recommended limit (70 to $80 \%$, Bruzual et al., 2000) as shown in Figure 4. The process that controls this parameter was not able to keep $\mathrm{RH}$ within the recommended limits, and low $\mathrm{RH}$ may reduce chick weight and result in longer incubation time (Muraroli \& Mendes, 2003), causing late embryo mortality (Decuypere et al., 2003; Pedroso, 2006). The Cp value (0.27) used to analyze process capacity was constant and with low variability, but below the lower tolerance limit (70 to $80 \%)$. Cpk (-0.32) indicated that the process was not within the average or specified values - only $16.62 \%$ of the data were within the $\mathrm{RH}$ range of 70 to $80 \%$ (Bruzual et al., 2000).

Incubator average environmental temperature $\left(36.8 \pm 0.9^{\circ} \mathrm{C}\right)$ indicates that only part of the data comply with specified temperature range $\left(37\right.$ to $\left.38^{\circ} \mathrm{C}\right)$, which indicates this is a CCP (French, 1997; Decuypere et al., 2003; Gustin, 2003; Hill, 2004; Boerjan, 2006; Gigli, 2007). The obtained $C p$ value to analyze process capacity was 0.19 , indicating that temperature remained constant and presented low variability, despite being below the lower tolerance limit, as
Identification of Critical Points of Thermal Environment in Broiler Production

presented in Figure 5. The obtained Cpk was -0.13, showing that the process is not centered within the specified temperature range of 37 to $38^{\circ} \mathrm{C}$. According to Gustin (2003) temperature variations of $\pm 1^{\circ} \mathrm{C}$ may have a strong impact in hatchability as it increases hatching time. The average $\mathrm{RH}$ value $(53.09 \pm 10 \%)$ was within the specified tolerance limits (50 to $60 \%$, Figure 6). The calculated $C p$ value (0.17), with constant variation, showed that $62.40 \%$ of the collected data complied with the specifications. The Cpk value (0.10) indicates the need of better control of $\mathrm{RH}$ in the incubator; despite being closer to the center, it still has some points outside the specified limits. Although there was better control of incubator relative humidity, indexes show that $37.6 \%$ of the data was below the lower limit and approximately 13\% were beyond the upper limit. This better control of the thermal environment of the incubator was obtained by a closer monitoring of the process to improve the rate of $85 \%$ hatchability of fertile eggs in 2008 in that hatchery. Decuypere et al. (2003) and French (1997) mentioned that hatchability is less affected by variations in relative humidity than variations in temperature, which must be maintained within an optimal range of 37 to $38^{\circ} \mathrm{C}$ to ensure good results, according to Wilson (1991).

In the hatcher room, average environmental temperature was $36.6 \pm 1.6^{\circ} \mathrm{C}$, and $68.69 \%$ of the collected data were within the tolerance limits (35.7 to $37^{\circ} \mathrm{C}$; Decuypere, 1992 ; Boerjan, 2006; Mauldin, 2007). Cp (0.13) presented constant variation, indicating that $68.69 \%$ of the measured temperatures were according to the recommended specifications. The obtained Cpk value (0.07) showed that the process that controls temperature was more consistent, despite some points outside the specified limits (Figure 7). Figure 8 shows that the average $\mathrm{RH}$ value in the hatcher $(55.7 \pm 6 \%)$ was below the lower limit of $65 \%$, which indicates considerable risk of lower efficiency, embryo weight reduction, and consequent chick mortality (Bruzual et al., 2000).

\section{Broiler houses}

The identified critical points identified in the evaluated broiler houses were environmental temperature and relative humidity. Average environmental temperatures in farm $A\left(26.4 \pm 1.8^{\circ} \mathrm{C}\right.$, Figure 9) and farm $\mathrm{B}\left(28.2 \pm 1.5^{\circ} \mathrm{C}\right.$, Figure 10) were within the threshold limits $\left(20\right.$ to $\left.28^{\circ} \mathrm{C}\right)$, as determined by Curtis (1983), Albright (1990), Moura (2001), Pereira (2005), and Owada et al. (2007).

The $C p$ value obtained in farm A (0.74) showed 
Menezes AG, Nääs IA, Baracho MS
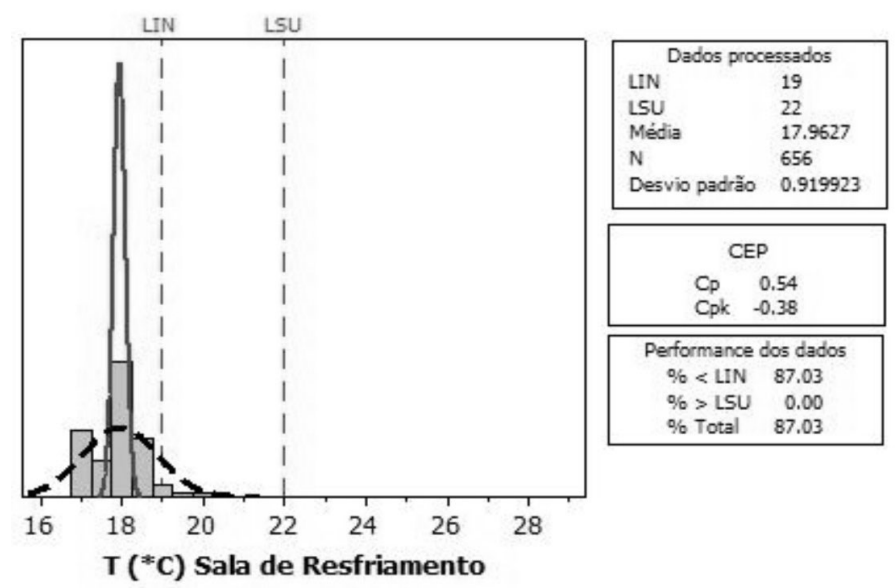

Performanoe dos dados

$\%<\operatorname{LIN} 87.03$

$\%>$ LSU 0.00

$\%$ Total 87.03

Figure 1 - Histogram of the environmental temperature in the egg cold storage room.
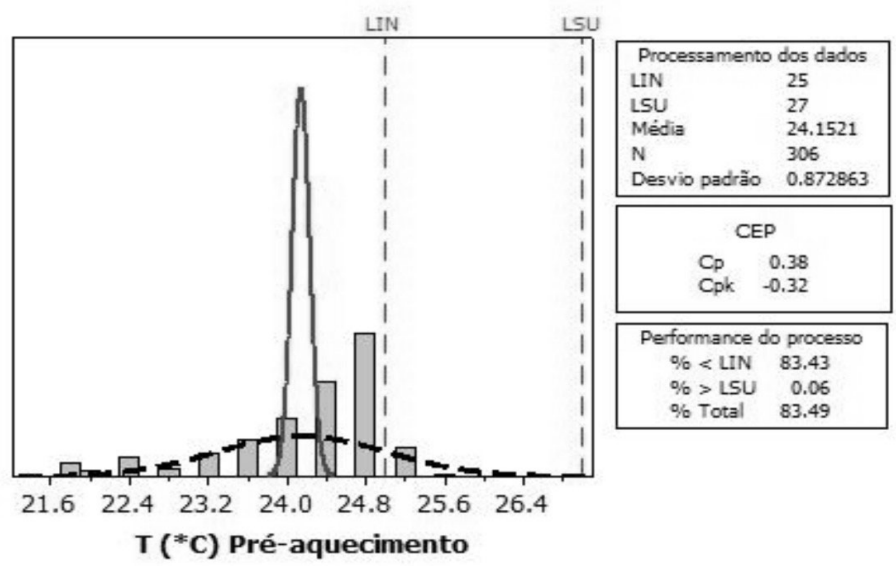

Figure 3 - Histogram of the environmental temperature in the egg pre-heating room.

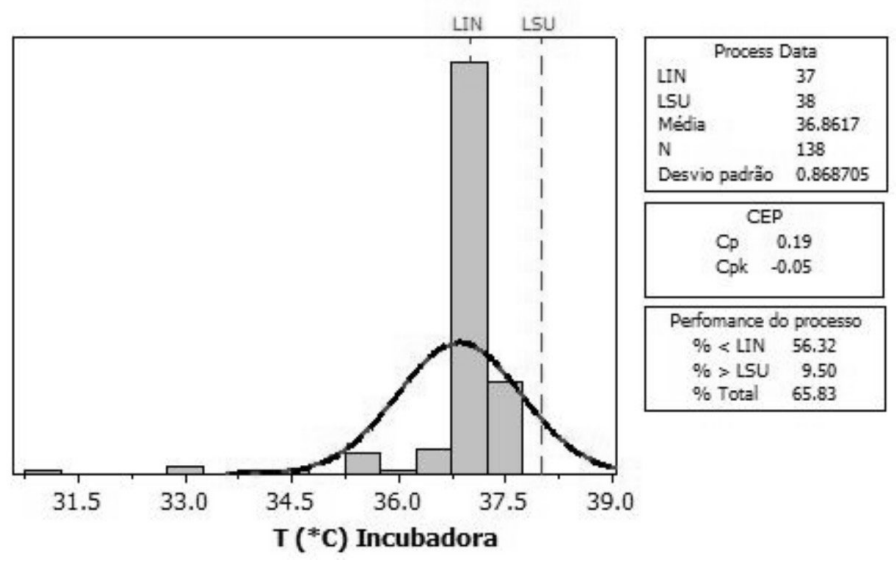

Figure $\mathbf{5}$ - Histogram of the temperature in the incubator.
Identification of Critical Points of Thermal Environment in Broiler Production

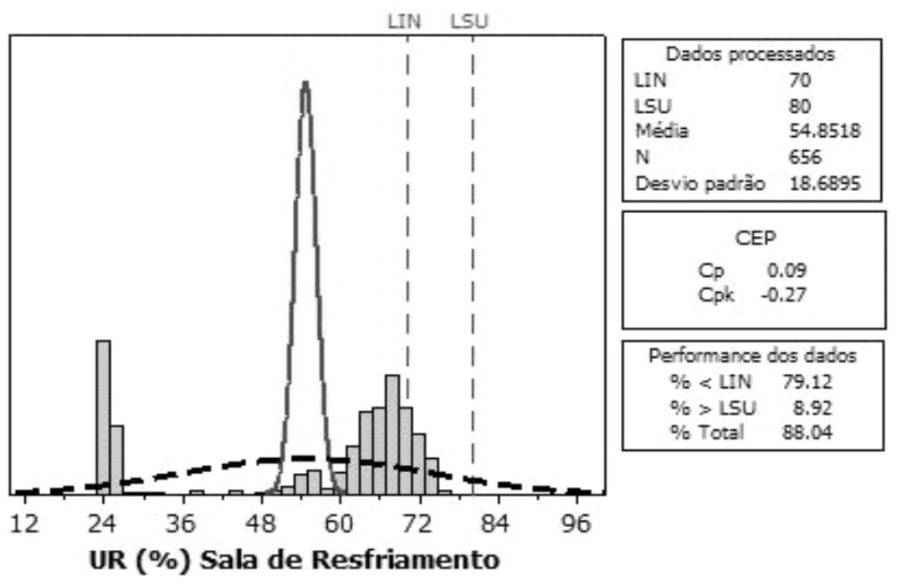

Figure $\mathbf{2}$ - Histogram of the relative humidity in the egg cold storage room.
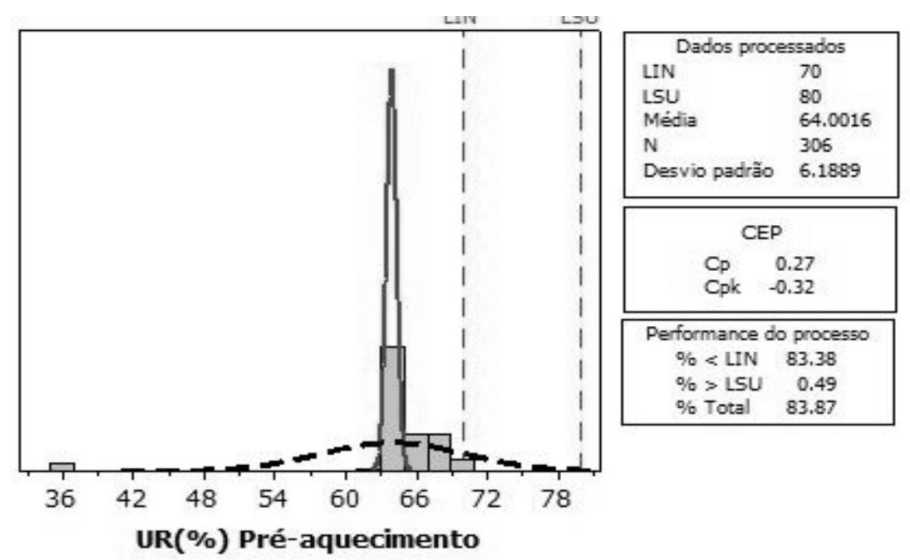

Figure 4 - Histogram of the relative humidity in the egg preheating room.

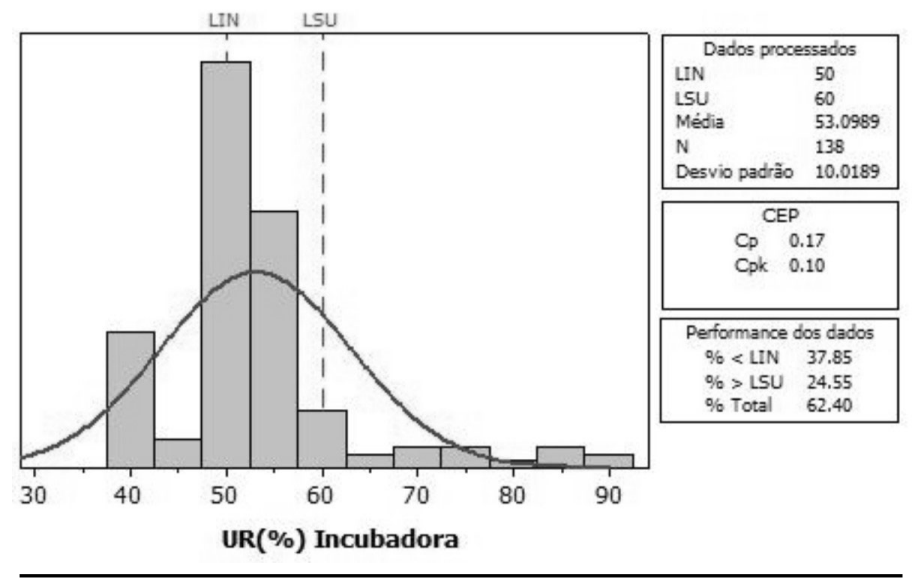

Figure 6 - Histogram of the relative humidity in the incubator. 
Menezes AG, Nääs IA, Baracho MS

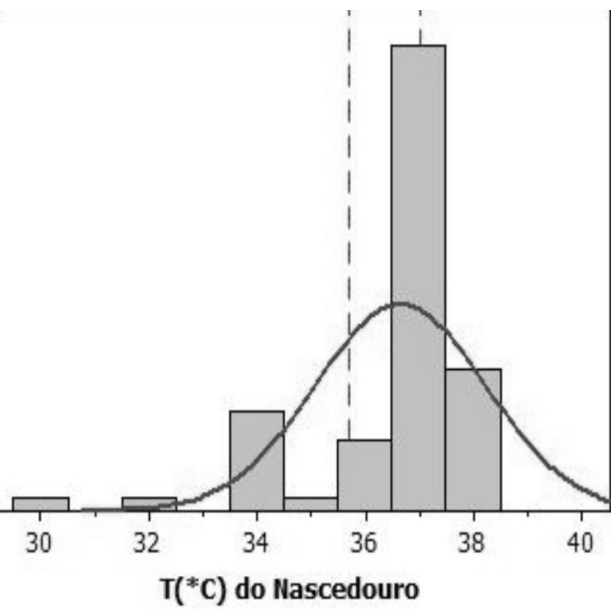

Figure 7 - Histogram of the temperature in hatcher room.

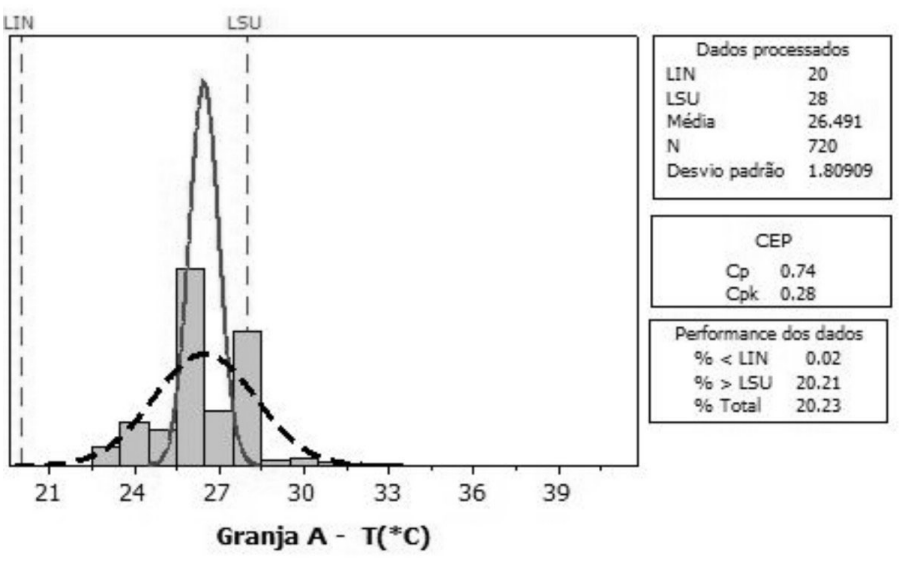

Figure 9 - Histogram of the temperature in the broiler house of farm A.

higher variation for the upper limit of $28^{\circ} \mathrm{C}$, with $20 \%$ of the data being higher than the established upper limit. The Cpk value (0.28) revealed that the process for the control of average temperature should be 24 ${ }^{\circ} \mathrm{C}$, but the obtained average value was 26.4 , indicating that the process, despite complying with the tolerance limits, was asymmetrical to the left, and therefore needs to be reviewed. As the broiler house was not insulated, internal environmental conditions were very sensitive to daily variations in the external environment, resulting in wide daily temperature amplitude (Moura, 2001).

In farm B the obtained Cp value (0.86) presented constant and increasing variation relative to the upper limit, showing that $55.9 \%$ of the house temperature was beyond the specified upper limit of $28{ }^{\circ} \mathrm{C}$. This
Identification of Critical Points of Thermal Environment in Broiler Production

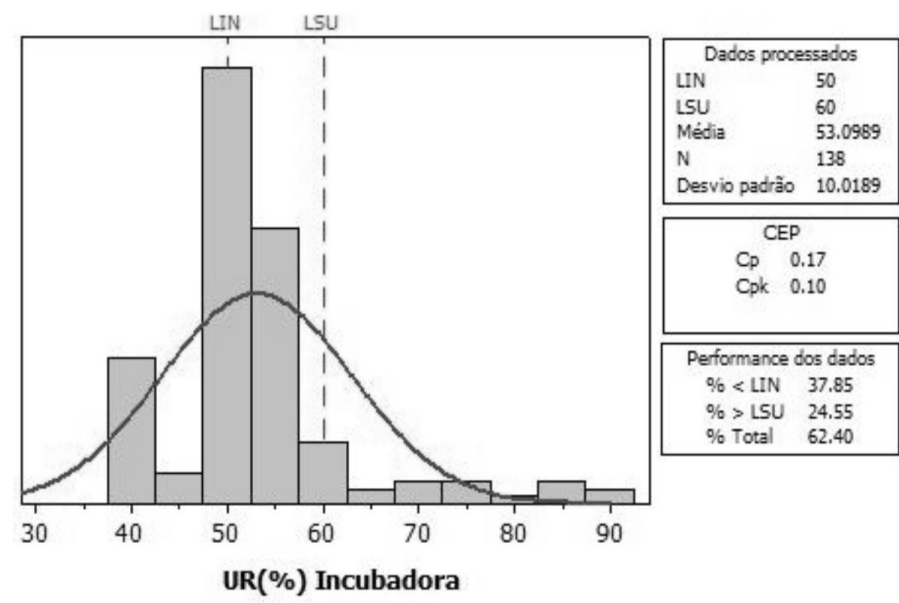

Figure $\mathbf{8}$ - Histogram of the relative humidity in the incubator.

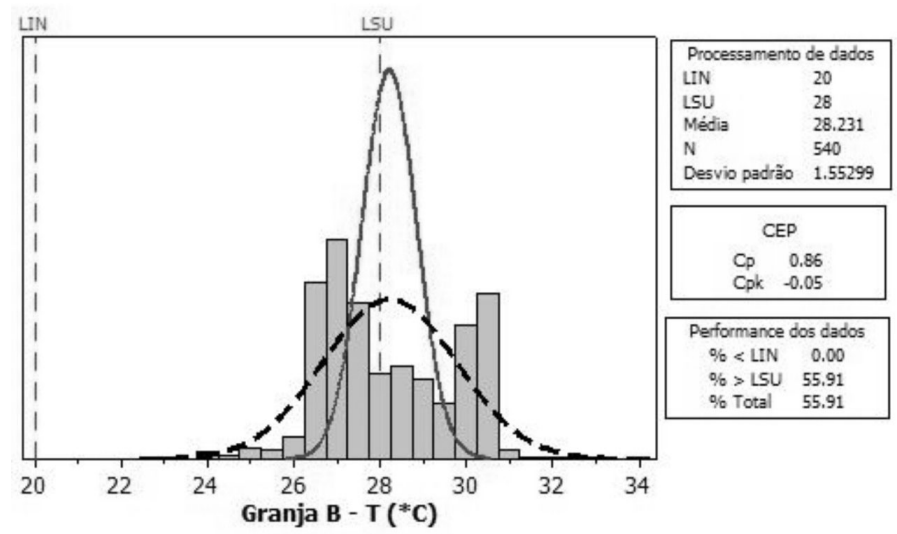

Figure 10 - Histogram of the temperature in the broiler house of farm $B$.

thermal environment is outside the zone considered as thermoneutral, causing heat stress and increasing mortality (Nääs, 1997; Silva, 2008). The data collected showed that the process was asymmetrical to the left, and was not able to comply with the Cpk index, with average expected values of $24^{\circ} \mathrm{C}$. Therefore, better monitoring and process control are strongly recommended.

Average $\mathrm{RH}$ values obtained in farm A $(43.47 \pm 6 \%$, Figure 11) and farm $B(53.01 \pm 8 \%$, Figure 12) were within the specified threshold of 40 to $80 \%$ (Miragliotta et al. 2001; Moura 2001). In farm A, Cp (1.09) showed higher variation as to the lower specified limit, with $28.52 \%$ of relative humidity data below this limit, which indicates that the process is acceptable. Cpk (0.19) shows that the process is not centered in the average 
Menezes AG, Nääs IA, Baracho MS

value of $60 \%$, and therefore corrective actions are required to obtain a more accurate control. The $\mathrm{Cp}$ value obtained for $\mathrm{RH}$ in farm $\mathrm{B}(0.78)$ indicates that data were concentrated and there was higher variation as to the lower limit, considering an optimal average value of $60 \%$. About $6.29 \%$ of the collected data were outside the established lower limit of $40 \%$. Cpk (0.51) indicated the need to review the process to obtain higher precision in the control of the internal environment, as the obtained average $\mathrm{RH}$ value was $53 \%$, which is below the optimal value of $60 \%$.

Air velocity value $\left(\mathrm{m} \mathrm{s}^{-1}\right)$ in farm $A$ was below the lower specified level of tolerance $\left(1 \mathrm{~m} \mathrm{~s}^{-1}\right)$, whereas in farm $B$, there was better control. The increase in temperature associated with lower air velocity is a critical control point, as it usually increases bird mortality (Owada et al., 2007). The ammonia levels collected in farms $A$ and $B$ were below the limit of 20ppm, which is considered acceptable (CIGR, 1994; Sampaio et al., 2005; Miragliotta, 2005; Owada et al., 2007). Average light intensity values recorded in both farms were homogenous.

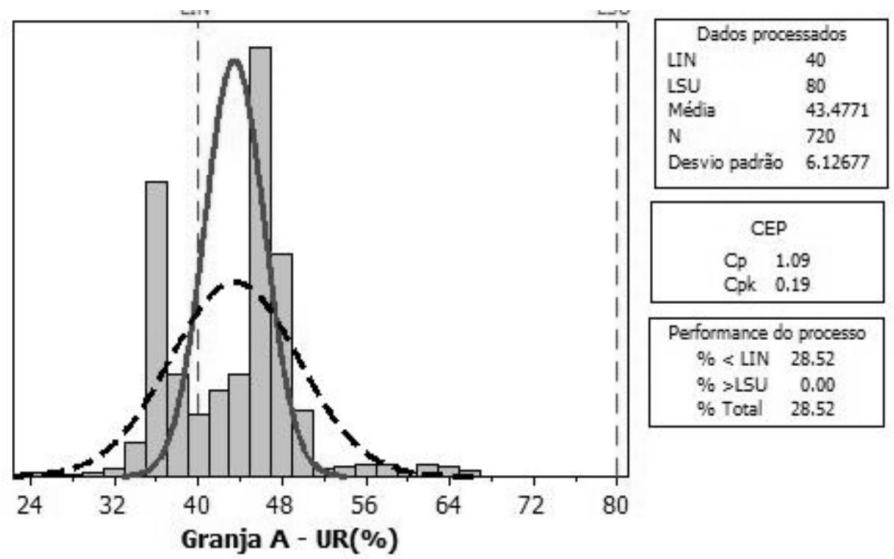

Figure 11 - Histogram of the relative humidity in the broiler house of farm $A$.

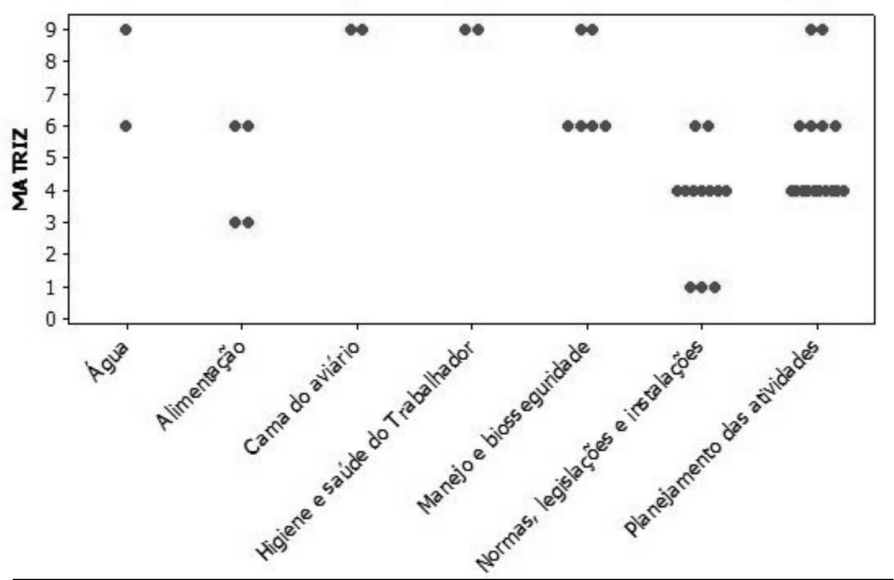

Figure 13 - Risk analysis matrix and classification of critical control points according to class.
Identification of Critical Points of Thermal Environment in Broiler Production

The risk analysis matrix built in Figure 13 shows a general scenario and indicates higher risk points ( 6 to 9) according to the BPGP Manual. These points require interventions as they are associated to factors that may result in higher bird mortality, or may lead to risks to bird welfare or to workers. The following steps were classified as critical control points (score 9): poultry litter (care and management), drinking water (availability and treatment), workers' hygiene and health (PPEs and training), management and biosecurity (broiler house location, isolation and entrance gate, activity planning, waste treatment system). The items feed and norms, legislation and facilities should be monitored and possible process improvements implemented.

CCPs in farm A were more severe as compared to farm B (Figure 14). The item bird feeding was classified as moderate because, although feeding practices were adequate, there were feed storage problems, increasing the biological risk of this process. As to drinking water, severity classification was due to deficiencies in drinker cleaning, which is an important requirement for drinkability and bird health.

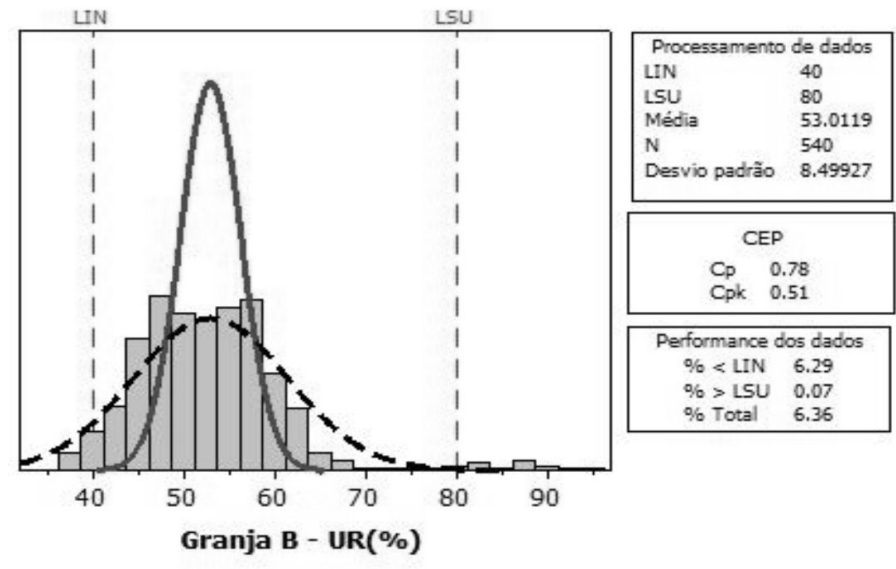

Figure 12 - Histogram of the relative humidity in the broiler house of farm $B$.

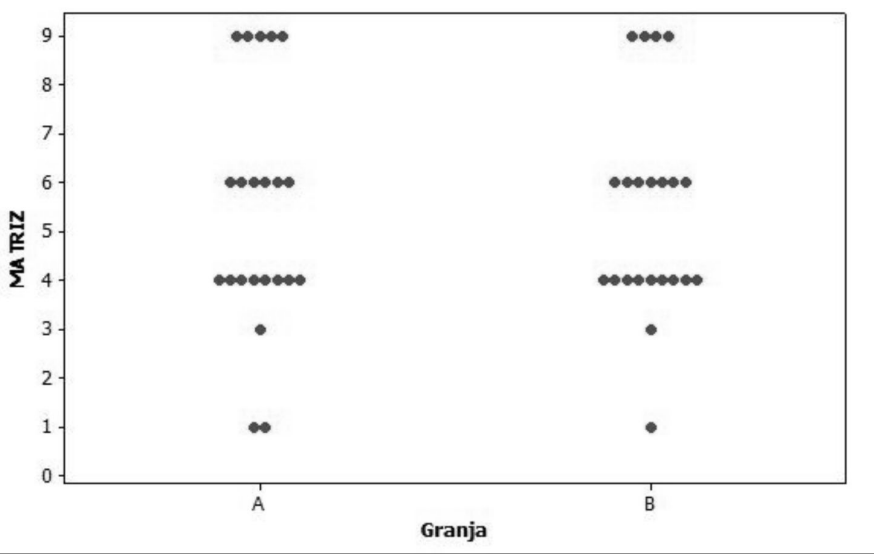

Figure 14 - Comparative classification of risk analysis matrices of farms $A$ and $B$. 


\section{CONCLUSIONS}

The critical control points evaluated in the different steps of the hatchery were ambient temperature and relative humidity, which severity can be minimized by implementing higher control. As to the broiler houses, environmental temperature and relative humidity were the identified critical points. When BPGPs were analyzed, the following critical control points were determined: poultry litter, feeding, drinking water, workers' hygiene and health, management and biosecurity, norms and legislation, facilities, and activity planning. The critical control points can have their severity minimized by the implementation of BPGPs and control of CCP, thereby providing better planning, monitoring, traceability, and safety for the broiler production chain, resulting in higher productivity and better animal welfare and worker wellbeing.

CCP analysis, associated with SPC control tools and good production practice guidelines, may contribute to quality assurance in industrial poultry production, bringing more reliability to the production chain.

\section{REFERENCES}

Albright L. Environment Control For Animals And Plants. St Joseph: ASAE; 1990. 453p.

Alencar MCB, Nääs IA, Gontijo LA. Effects of labor motivation in poultry production. Revista Brasileira de Ciência Avícola 2007; 9 (4):249-253.

Almeida CR. O Sistema HACCP como instrumento para garantir a inocuidade dos alimentos. Higiene Alimentar; 1998 citado em 2008 maio 10 . Disponível em: www.cve.saude.sp.gov.br/htm/hidrica/ IF_HACCP.htm.

Bessei W. Welfare of broilers. World's Poultry Science Journal 2006; 62(3):455-66.

Boerjan ML. Incubação em estágio único para melhorar a uniformidade. Anais da Conferência APINCO de Ciência e Tecnologia Avícolas; 2006; Santos, São Paulo. Brasil. Campinas: FACTA; 2006. p. 325-333.

Boleli IC. Fatores que afetam a eclodibilidade e qualidade dos pintos. In: Macari M, Gonzales E., editores. Manejo da incubação. 2. ed. Campinas: Fundação APINCO de Ciência e Tecnologia Avícolas; 2003. p.394-434.

BRASIL. Política Nacional de Recursos Hídricos. CONAMA. Resolução n 357/05 citado em 2008 fev 12 . Disponível em: www.mma.gov.br/ port/conama/res/res05/res35705.pdf.

Bruzual JJ, Peak SD, Brake J, Peebles ED. Effects of relative humidity during incubation on hatchability and body weight of broiler chicks from young breeder flocks. Poultry Science 2000; 79(6):827-830.
Cesari DL, Nascimento ER. Análise de perigos e pontos críticos de controle. 2.ed. Campinas: Sociedade Brasileira de Ciência e Tecnologia de Alimentos; 1995. 28p.

Commission Internationale Du Génie Rural - CIGR. Aerial environment in animal housing: concentrations in and emissions from farm buildings. Dublin; 1994. p.116.

Curtis SE. Environmental management in animal agriculture. Ames: The lowa State University Press; 1983. p.410.

Decuypere $\mathrm{K}$, Michels $\mathrm{H}$. Incubation temperature as a management tool: a review. World's Poultry Science Journal 1992; 48:27-38.

Decuypere E, Malheiros RD, Moraes VMB, Bruggeman V. Fisiologia do embrião. In: Macari M, Gonzales E, editors. Manejo da incubação. 2.ed. Campinas: Fundação APINCO de Ciência e Tecnologia Avícolas; 2003. p.65-94.

Dillon M, Griffith CJ. How to HACCP: an illustrated guide. 3rd ed. Humberside: MD Associates; 2001. 145p.

Empresa Brasileira de Pesquisa Agropecuária. Boas práticas de produção de frangos de corte. Concórdia: Embrapa Suínos e Aves; 2007. $28 p$.

Estevez I. Density allowances for broilers: where to set the limits? Poultry Science 2007; 86:1265-1272.

French NA. Modeling incubation temperature: the effects of incubator design, embryonic development, and egg size. Poultry Science 1997; 76:124-133.

Gigli ACS. Monitoramento do ambiente em incubatório visando melhorias na produção [mestrado]. Campinas: Faculdade de Engenharia Agrícola, Universidade Estadual de Campinas; 2007.

Gustin PC. Manejo do pinto no incubatório, expedição, transporte e alojamento na granja. In: Macari M, Gonzales E, editores. Manejo da incubação. Campinas: FACTA; 2003. p.200-266.

Hill D. Titulo do artigo. Anais do $5^{\circ}$ Simpósio Técnico de Incubação, Matrizes de Corte e Nutrição; 2004; Balneário Camboriú.

Jones TA, Donnelly CA, Dawkins MS. Environmental and management factors affecting the welfare of chickens on commercial farms in the United Kingdom and Denmark stocked at five densities. Poultry Science 2005; 84:1155-1165.

Kaltofen KS. The effect of air movements on hatchability and weight loss of chicken eggs during artificial incubation. In: Carter TC, Freeman BM, editors. The fertility and hatchability of the hen's egg. Edinburgh, UK: Oliver \& Body; 1969. p.177-190.

Macari M. Água na avicultura industrial. Jaboticabal: FUNEP; 1996. $128 p$.

Mauldin JM, Kuzniak SF, Gardino TL. Comparisons of hatchability measures in Jamesway platinum single stage incubators with Jamesway multistage incubators in a commercial broiler hatchery in Georgia. Georgia: UG; 2007. 42p. Available from: http:// www.poultry.uga.edu/about/documents/ProgramReview2009.pdf. 


\section{Menezes AG, Nääs IA, Baracho MS}

Mendes AA, Watkins SE, England JA, Saleh EA, Waldroup AL, Waldroup PW. Influence of dietary lysine level and arginine: lysine rations on performance of broilers exposit to heat or cold stress during the period of three to six weeks of age. Poultry Science 1997; 76:472-481.

MINITAB. Programa Software, version 15 [Cd-Rom]; 2005.

Miragliotta MY, Nääs IA, Baracho MS. Avaliação da qualidade do ar dentro do galpão de produção de matrizes pesadas - estudo de caso. Anais do $30^{\circ}$ CONBEA; 2001; Jaboticabal, São Paulo. Brasil. p.1-4.

Miragliotta MY. Avaliação das condições do ambiente interno em dois galpões de produção comercial de frangos de corte, com ventilação e densidade populacional diferenciados doutorado . Campinas: Faculdade de Engenharia Agrícola, Universidade Estadual de Campinas; 2005.

Moraes DT, Lara LJC, Baiao NC, Cançado SV, Gonzalez ML, Aguilar CAL, Lana AMQ. Efeitos dos programas de luz sobre desempenho, rendimento de carcaça e resposta imunológica em frangos de corte. Arquivo Brasileiro Medicina Veterinária Zootecnia 2008; 60(1): 201208.

Moura DJ. Ambiência na avicultura de corte. In: Silva IJO. Ambiência na produção de aves em clima tropical. Piracicaba: FUNEP; 2001. p.75-149.

Moura DJ. Avaliação da eficiência térmica de instalações avícolas com diferentes orientações, sombreamento e ventilação doutorado. Campinas: Faculdade de Engenharia Agrícola, Universidade Estadual de Campinas; 1998.

Muraroli A, Mendes AA. Manejo da incubação, transferência e nascimento do pinto. In: Macari M, Gonzales E., editors. Manejo da incubação. 2.ed. Campinas: Fundação APINCO de Ciência e Tecnologia Avícolas; 2003. p.180-198.

Nääs IA. Ventilação e climatização para frangos de corte. Anais da Conferência Apinco de Ciência e Tecnologia Avícolas; 1997; São Paulo, SP. Brasil. p.108-119.

Nääs IA, Baracho MS, Miragliotta M. Condições de qualidade do ar em granjas de produção de frangos de corte [Cd Rom]. Anais do $29^{\circ}$ Congresso Brasileiro de Engenharia Agrícola; 2001; Fortaleza. Ceará. Brasil.

Nicholson AD. Condições de incubação e desempenho do frango. São Paulo: Agroceres; 2006. 2p.

OSHA. Guia sistemas de gestão da segurança e saúde no trabalho: revisão; 1999.

OSHA. Occupational Safety \& Health Administration; 1991 cited 2008 jun 28 . Available from: www.osha.gov.

Owada NA, Nääs IA, Moura DJ, Baracho MS. Estimativa de bem estar de frango de corte em função da concentração de amônia e grau de luminosidade no galpão de produção. Revista de Engenharia Agrícola 2007; 27(3):611-618.
Identification of Critical Points of Thermal Environment in Broiler Production

Pedroso AA, Café MB, Leandro NSM, Stringhini JH, Chaves LS. Desenvolvimento embrionário e eclodibilidade de ovos de codornas armazenados por diferentes períodos e incubados em umidades e temperaturas distintas. Revista Brasileira Zootecnia 2006; 35(6):2344-2349.

Pereira DF. Metodologia para estimativa de bem estar de matrizes de frango de corte utilizando monitoramento digital e construção de modelos de simulação doutorado. Campinas: Faculdade de Engenharia Agrícola, Universidade Estadual de Campinas; 2005.

Salgado DD, Nääs IA, Pereira DF, Moura DJ. Modelos estatísticos indicadores de comportamentos associados a bem estar térmico para matrizes pesadas. Engenharia Agrícola 2007; 27(3): 619-629.

Sampaio CAP, Naas IA, Nader A. Gases e ruídos em edificações para suínos: aplicação das normas NR-15, CIGR e ACGIH. Engenharia Agrícola 2005; 25(1):10-18.

Silva RBTR. Normas de produção de animais submetidos a sistema intensivo: cenário da legislação nacional sobre bem estar animal mestrado. Campinas: Universidade Estadual de Campinas; 2008.

Schmidt GS, Figueiredo EAP, Avila VS. Incubação: estocagem dos ovos férteis. Concórdia: Embrapa Suínos e Aves; 2002. 5p.

Pinotti RN, Paulillo LFO. A estruturação da rede de empresas processadoras de aves no Estado de Santa Catarina: governança contratual e dependências de recursos. Gestão de Produção 2006; 13(1):167-177.

Wilson HR. Interrelationships of egg size, chick size, posthatching growth and hatchability. World's Poultry Science Journal 1991; $47(2): 5-20$. 